\title{
The Determinants of the Career Choice of International Students in South Africa
}

\author{
Olawale Fatoki \\ Department of Business Management, Turfloop campus, University of Limpopo, \\ Limpopo Province, South Africa Email: Olawale.fatoki@ul.ac.za
}

\author{
Doi:10.5901/mjss.2014.v5n23p668
}

\begin{abstract}
The primary objective of the study was to determine the factors that influence the career choice of international students in South Africa. The study used the quantitative research approach and a descriptive research design. Data for the research was gathered through the use of self-administered questionnaire in a survey. The participants in the survey were international students pursuing business related courses at two universities located in the Limpopo and Gauteng provinces of South Africa. Convenience and snowball sampling methods were used to collect data from seventy five respondents. The results indicated that there are multiple influences on the career choice of international students. The most important determinants of the career choice of international students pursuing business courses are the interest in the course, the prestige of the course, the prospect of well-paying jobs, bright future prospects, and the influence of job opportunities, the influence of parents and the subjects passed at Matric or equivalent level.
\end{abstract}

Keywords: determinants, career choice, international students, South Africa

\section{Introduction}

Walker et al. (2010) point out that the South African higher education sector has opened up to students from other countries within Africa and outside. Changes in higher education in South Africa have been driven by developments in the international context such as the effects of globalisation. Better educational opportunities in South Africa compared to other countries are a major driver of the migration of international students. According to the International Education Association of South Africa (2004), within the continent of Africa, particularly the sub-continent of Southern Africa, South Africa's higher education sector is the strongest and most diverse offering a full range of courses and qualifications. Many of South Africa's universities are world-class academic institutions at the cutting edge of research in various spheres. South Africa's leading role in Africa, its strong research universities and its relatively advanced stage of development make it an ideal base for international students.

Watson et al. (2010), Mashige and Oduntan (2011) and Olamide and Olawaiye (2013) acknowledge that students often experience problems when deciding on their career choices. The career choice that a student makes can impact on the student's enjoyment of such career in the future. Career choice decisions will impact on students throughout their lives. Issa and Nwalo (2008) acknowledge that many youths go into unsuitable careers due to ignorance, inexperience and peer pressure. When this occurs, these youths constitute nuisance to themselves and their employers and are unable to contribute meaningfully to the society. The choice of career is one of the major areas of concern for young people nearing the end of their schooling (Alberts et al. 2003).

Borchert (2002) and Haase and Lautenschläger (2011) remark that increasing the level of economic activity is one of the major goals of countries. To achieve this goal, human resources must be efficiently allocated. Therefore, there is a need to understand the motivations for the career choices of students. Understanding the motivations of the career choices of students is highly relevant for the socio-economic role of universities. Many factors affect the career choices of students. Identifying these factors would give parents, educators, and industry an idea as to where students place most of their trust in the career selection process. Mudhovozi and Chireshe (2012) note that understanding the determinants of career choice will help educators to orientate students in career path planning. In addition, it will help policy-makers to understand students' career decisions. Investigating and better understanding the factors that contribute to career choice is a topic of recurring interest in higher education as it can impact on the development of a society.

Singaravelu et al. (2005) point out that most of the studies on the determinants of the career choice of students have focused on local students. Research related to factors influencing the career choices of international students has been scarce. This may be due to a commonly held belief that international students have come to their host countries with well-defined educational and vocational objectives. However, some international students come from countries 
where formal career guidance systems do not exist and opportunities for career exploration are limited. Furthermore, some international students may find it necessary to reassess their career choices, especially if incongruence develops between their interest and abilities.

\section{The Objective of the Study}

Understanding the determinants of career choice is highly significant in career path planning and the social-economic development of a country. The primary objective of the study is to determine the factors that influence the career choices of international students in South Africa.

\section{Literature Review}

The Theory of Planned Behaviour by Fishbein and Ajzen (1975), Ajzen (1991) assert that there is a link between beliefs and behaviour. The best predictor of the behaviour of an individual is their intention to perform that behaviour. Intentions are influenced by three factors which are the attitude towards performing the behaviour, subjective norms and perceived behavioural control. Zellweger et al. (2008) point out that the attitude towards performing the behaviour links behaviour to a certain outcome. The attitude towards the behaviour is determined by the beliefs about the potential outcomes of that behaviour. Subjective norms are influenced by normative beliefs. These include family expectations when an individual considers performing a particular act. Perceived behavioural control refers to an individual's perception of the ease or difficulty of performing the behaviour of interest.

The Social Cognitive Theory by Bandura (1986), (1989) proposes a theory to explain the developmental changes that people go through in the course of their lives. According to Bandura (1989), the Social Cognitive Theory supports a model of causation involving triadic reciprocal determinism. "In this model of reciprocal causation, behaviour, cognition and other personal factors and environmental influences all operate as interacting determinants that influence each other bidirectionally". Reciprocal causation does not mean equal strength for the different sources of influence. This suggests that behaviour, cognition, personal factors, and environmental influences can differently impact on career choice. The Social Cognitive Career Theory developed by Lent et al. (1994) built on the work of Bandura (1986). The Social Cognitive Career Theory suggests that career behaviour is a result of interaction between self-efficacy, outcome expectation and goals. Self-efficacy describes the beliefs that people have about their ability to successfully complete the requirements for a given task. Outcome expectations are the beliefs that are related to the consequences of performing a specific behaviour. A goal is described as the decision taken to begin a particular activity.

Sarwar and Azmat (2013) note that career choices are not made on standalone basis. There are multiple influences on career choice decisions. Watson (2004) finds that the possibility of receiving a sponsorship/bursary can highly influence the career choice of students especially if tuition fees are financially demanding. Cutler et al. (2006) find that medical students in the field of psychiatry rate the field's intellectual content and quality of life as some of the significant motivating factors influencing career choice. According to Bojuwoye and Mbanjwa (2006), career development is a socially constructed process involving complex interactions among different structures, forces, and systems all constituting spheres of influence. Results revealed that family variables such as parental high expectations of children as well as factors such as prestige and status of some occupations, school curricular subjects, academic performance, teacher influences and peer pressure have strong positive influences on career choices.

Maharaj (2008) points out that career choice is dependent on various factors. These include funding, type of school attended, cultural factors, race and gender. Other factors that influence career choice are job experience, personal factors, prestige, lifestyle preference, personality type and commitment. In addition, factors such as enthusiasm, challenge, variety in a profession, motivation to help other people, financial reward and the ability to define one's own personal goals are important determinants of career choice. Bandura et al. (2001) examine the socio-cognitive factors that shape children's career aspirations and trajectories among 272 early adolescents. The study finds that students' perceived efficacy rather than their actual academic achievement is the key determinant of their perceived occupational self-efficacy and preferred choice of work life. According to Edwards and Quinter (2012), the personal interests of students is the most important factor influencing career choice. The personal interests of students in particular academic subjects, interests in tasks related to the job, the fit between their personality and the needs of the job, confidence in achieving a job, and need to make a decent salary. Individuals are more attracted towards the professions which are dynamic and which gives many opportunities for personal development.

Salami (2006) finds that family involvement is the most significant predictor of career choice in gender-dominated occupations. Family involvement can be described as the extent to which the parents or family members are involved in 
the career plans of children. The family can provide information and guidance directly or indirectly, to influence a young person's career choice. Family involvement also includes the extent to which parents provide encouragement, responsiveness, approval and financial support in matters concerned with the career plans of their children

Kniveton (2004), Falaye and Adams (2008) and Mudhovozi and Chireshe (2012) conclude that the school where a student is educated is an important influence on career choice. Schools are social institutions that reinforce appropriate behaviour, interests and occupations. Teachers, like parents, are viewed as key players in the career paths that young people eventually pursue. Teachers encourage students to take certain subject options that are congruent with their aptitudes and abilities. School teachers can identify aptitudes and abilities, and encourage students to take certain subject options, or take part in work experience, or employment visits. Private schools seem to provide more comprehensive information and counselling on career choices than public schools. Constructs such as curricular subjects, quality of teaching, student participation in school activities and learning materials for the student can seriously impact on career choice of students. Mashige and Oduntan (2011) find that the highest rated factors which influence their choice of optometry is the desire to help other people, job availability after graduation, subjects passed and points obtained in the matric year and the potential to earn a good salary Few respondents rate news and other media and the failure to gain admission to study other degrees as an important factors. Van Zyl and de Villiers (2011) report that accounting students' choice is driven mainly by job security, job satisfaction, aptitude for accounting and potential future earnings.

Sarwar and Azmat (2013) point out that the three broad categories of factors that influence career choice are (1) Personal factors such as the prestige given to individual to the type of career. (2) Socio-economic factors such as the job opportunities given by the environment, and the needs of the society and (3) Socialisers such as parents, siblings, media and significant others. In addition, work related factors are also important while selecting a career. Work related factors this include working hours, conditions and expected income as well. The awareness of careers also contributed towards making a career decision. Singaravelu et al. (2005) and Maharaj (2008) find that socialisers especially parents are a major factor influencing career choice. Parental acceptance, not necessarily interest is a major component of career choice. Siblings, peers and television do not have a major influence. Extrinsic values, such as money and status and prestige are also important determinants of career choice. Environmental factors, such as culture, and community are also important determinants. Haase and Lautenschläger (2011) also grouped the determinants of career into three components. These are (1) status orientation (2) self-realisation and (3) self-determination.

\section{Research Methodology}

The study used the quantitative research approach with a descriptive research design. Data for the research was gathered through the use of self-administered questionnaire in a survey. The participants in the survey were international students pursuing business courses at two South African universities located in the Limpopo and Gauteng provinces. Participation in the survey was voluntary and the participants were assured of confidentiality. Convenience and snowball sampling methods were used. The questionnaire was divided into two parts (1) biographical and (2) career choice. A sixteen-item questionnaire was developed to measure to measure the career choice of international students. The questionnaire was adopted from previous studies on the determinants of career choice of students such as Singaravelu et al. (2005) and Sarwar and Azmat (2013). Five-point Likert scale questions ranging from "1 not at all important" "2 slightly important" "3 important" "4" very important and " 5 extremely important were used to measure the determinants of the career choice of international students. The questionnaire was pre-tested in a pilot study of twenty international students. The pilot study was conducted to evaluate content and face validity. Two faculty members also examined the questionnaire. The feedback of the participants in the pilot study was used to modify the questionnaire. The Cronbach's alpha was used as a measure of reliability. Nunnally (1978) recommended a rule of thumb of 0.7 as the minimum acceptable coefficient. The study used descriptive statistics for data analysis.

\section{Results and Discussions}

\subsection{Response rate and biographical information}

One hundred and twenty six questionnaires were distributed to international students and seventy five questionnaires were returned. The response rate was $59.5 \%$. There were forty one male respondents and thirty four female respondents. Thirty eight respondents were in the first year of study, nineteen respondents in the second year of study and sixteen respondents in the third year of study. All the respondents were international students from Africa pursuing business 
courses.

\subsection{The determinants of career choice of international students}

Table 1: Determinants of career choice

\begin{tabular}{|l|c|c|}
\hline Factors & Mean & Standard deviation \\
\hline Interest in the course & 4.68 & 0.94 \\
\hline The prestige of the course (high social status and respect for the course) & 4.12 & 0.84 \\
\hline The government in my home country wanted me to do the course & 1.15 & 0.79 \\
\hline Influence of my parents/family & 3.05 & 0.81 \\
\hline Influence of my friends & 1.07 & 0.69 \\
\hline Influence of my secondary school teacher & 1.12 & 0.62 \\
\hline Influence of the media or press & 1.05 & 0.62 \\
\hline Influence of my secondary school counsellor & 1.55 & 0.78 \\
\hline The prospects of well-paying jobs & 4.25 & 0.96 \\
\hline The bright future prospects of the course & 4.20 & 0.94 \\
\hline Influence of job opportunities & 4.25 & 0.94 \\
\hline Previous working experience related to the course & 1.02 & 0.71 \\
\hline Participation in career/open day in secondary school & 2.20 & 0.82 \\
\hline The subjects that I passed at Matric/equivalent level & 4.08 & 0.92 \\
\hline Failure to secure a place in other degree & 1.19 & 0.75 \\
\hline Availability of bursary & 3.24 & 0.77 \\
\hline
\end{tabular}

The results as depicted by table 1 indicate that there are multiple influences on the career choice decisions of international students. The Cronbach's alpha coefficients were greater than 0.70 for all the determinants of career choice. The most important determinants of the career choice of international students pursuing business courses are interest in the course, the prestige of the course, prospect of well-paying jobs, bright future prospects, influence of job opportunities and the subjects passed at Matric or equivalent level. The influence of parents and availability of bursary are also important factors. The results show that personal factors such as the interest in the career and the prestige of the career are very important determinants. In addition, socio-economic factors such as the job opportunities given by the environment, the prospects of well-paying jobs and the bright future prospects of the career are also very important. Furthermore, the influence of socializers especially parents are also important determinants. City Press (2012) reports that some of the most sought skills from graduates are in finance, accounting and management. This suggests that business students stand a better chance of being employed than non-business students. Therefore, the availability of jobs is a major factor in career choice decisions.

The findings of the study are consistent with the results of previous empirical studies. Maharaj (2008) points out that career choice is dependent on various factors. These include funding, type of school attended; cultural factors race and gender; job experience and personal factors prestige; lifestyle preference; personality type and commitment. Other important factors include enthusiasm, challenge, variety in a profession; motivation to help others; financial reward and the ability to define one's own personal goals. Haase and Lautenschläger (2011) reveal that the determinants of career choice can be grouped into three components. These are status orientation, self-realisation and self-determination. Sarwar and Azmat (2013) point out that the three broad categories of factors that influence career choice are personal factors such as the prestige given to individual to the type of career, socio-economic factors such as the job opportunities and socialisers such as the influence of parents. Singaravelu et al. (2005) find that family influence is one of the most prominent determinants of career choice for international students.

\section{Conclusion}

The primary objective of the study is to determine the factors that influence the career choice of international students. Most of the studies on the career choice of students have focused on local students. Research related to factors influencing the career choices of international students has been scarce. Understanding the motivations of the career choices of students is highly relevant for the socio-economic role of universities. In addition, understanding the determinants of career choice will help educators to orientate students in career path planning. The results indicate that there are multiple influences on the career choice of international students. The most important determinants of the 
career choice of international students pursuing business courses are interest in the course, the prestige of the course, prospect of well-paying jobs, bright future prospects, influence of job opportunities and the subjects passed at Matric or equivalent level. The influence of parents and availability of bursary are also important factors. The results show that personal factors, socio-economic factors and socialisers are important determinants of career choice. The results from this study suggest the need for career counsellors to design programmes that take into account the influences of personal factors, socio-economic factors and family in advising students on their career choices. Other studies can investigate the effect of gender and area of study on the career choice of university students. The study was conducted at only two universities. Thus, caution must be exercised in interpreting the findings and in making generalisations. Data collection could be expanded to include a larger sample from other universities in South Africa.

\section{References}

Alberts, C., Mbalo, N. L. \& Ackermann, C. J. (2003). Adolescents' Perceptions of the Relevance of Domains of Identity Formation: A South African Cross-Cultural Study. Journal of Youth and Adolescence, 32 (3), 169-184.

Ajzen, I. (1991). The theory of planned behaviour. Organizational Behaviour and Human Decision Processes, 50 (2), 179-211

Bandura, A. (1986). Social foundations of thought and action: A social cognitive theory. Englewood Cliffs, NJ: Prentice-Hall.

Bandura, A. (1989). Social cognitive theory. In R. Vasta (Ed.), Annals of child development. Vol. 6. Six theories of child development (pp. 1-60). Greenwich, CT: JAI Press.

Bandura, A., Barbaranelli, C., Caprara, G., \& Pastorelli, C. (2001). Self-efficacy beliefs as shapers of children's aspirations and career trajectories. Child Development, 72, 187-206.

Bojuwoye, O., \& Mbanjwa, S. (2006). Factors impacting on career choices of Technikon students from previously disadvantaged high schools. Journal of Psychology in Africa, 1: 316.

Borchert, Michael, (2002), Career choice factors of high school students. [Online] Available:http://www2.uwstout.edu/content/lib/ thesis/2002/2002borchertm.pdf (June 5, 2014)

City Press (2012), Young, Jobless and Desperate. Degrees with no Guarantees. [Online] Available: http:// www.citypress.co.za /SouthAfrica/News/Young-jobless- and-desperate-Degrees- with-noguarantees- 20120616. (August 19, 2013).

Cutler, J.L., Alspector, S.L., \& Harding K.J. (2006). Medical students' perceptions of psychiatry as a career choice. Academic Psychiatry, 30, 144-149

Edwards, K., \& Quinter, M. (2012). Factors Influencing Students Career Choices among Secondary School students in Kisumu Municipality, Kenya. Journal of Emerging Trends in Educational Research and Policy Studies, 2 (2): $81-87$

Falaye, F.W., \& Adams, B.T. (2008). An assessment of factors influencing career decisions of in-school youths. Pakistan Journal of Social Sciences, 5(3): 222- 225

Fishbein, M., Ajzen, I., (1975). Belief, attitude, intention, and behavior. An introduction to theory and research. New York. AddisonWesley

Haase, H., Lautenschläger, A., (2011). Career choice motivations of university students. International Journal of Business Administration, 2(1): 1-13

International Association of South Africa (2004), Public Universities in South Africa. [Online] Available: http://www.nu. ac.za/ieasa/ (April 27, 2013)

Issa, A.O., \& Nwalo, K.I (2008). Factors affecting the career choice of undergraduates in Nigerian Library and information science schools. African Journal of Library, Archives and Information Science, 18 (1): 23-32

Kniveton, B.H (2004). The influences and motivations on which students base their choice of career. Journal of Research in Education, 72: 47-59.

Lent, R.W., Brown, S.D., \& Hackett, G. (1994). Toward a unifying social cognitive theory of career and academic interest, choice, and performance. Journal of Vocational Behaviour, 45, 79-122.

Maharaj, R. (2008), An investigation into the retention/dropout of mechanical engineering students at a FET College. Master"s Dissertation. University of KwaZulu-Natal. Pietermaritzburg

Mashige, K.P., \& Oduntan, O.A., (2011). Factors influencing South African optometry students in choosing their career and institution of learning. The South African Optometrist, 70(1) 21-28

Walker, Melanie, Mclean, Monica, Dison, Arona,, Vaughan, Rosie (2010), Development Discourses: Higher Education and Poverty Reduction in South Africa. ESRC Award number RES-167-25-0302 [Online]Available:http://www.nottingham.ac.uk/ EducationResearchProjects/DevelopmentDiscourses.index.aspx. (July 8, 2014)

Mudhovozi, P., \& Chireshe, C. (2012). Socio-demographic factors influencing career decision-making among undergraduate psychology students in South Africa. Journal of Social Sciences, 31(2): 167-176.

Nunnally, J. C. (1978). Psychometric theory (2nd ed.). New York: McGraw-Hill.

Olamide, S.O., \& Olawaiye, S.O. (2013). The factors determining the choice of career among secondary school students. The International Journal of Engineering and Science, 2(6):33-44

Salami, S.O. (2006). Influence of culture, family and individual differences on choice of gender-dominated occupations among female students in tertiary institutions. Gender and Behaviour,4(2): 814- 833

Sarwar, A., Azmat, A. (2013). Factors Having Impact on the Career Decisions: Study of Business Graduates in Pakistan. Business 
Management Dynamics, 2(7): 9-19.

Singaravelu, H., White, L., \& Bringaze, T. (2005). Factors influencing international students' career choice: A comparative study. Journal of Career Development, 32, 46-59.

Van Zyl, C., \& de Villiers, C. (2011). Why some students choose to become chartered accountants (and others do not). Meditari Accountancy Research, 19(1/2): 56 -74

Watson, M.B. (2004). Post-modern (narrative) career counselling and education. Perspectives in Education, 22 (1): 169-170.

Watson, M., McMahon, M., Foxcrof, C., \& Els, C (2010). Occupational aspirations of low socio-economic Black South African children. Journal of Career Development, 37(4): 717-734.

Zellweger, T., Sieger, P., Halter, F (2010). Should I stay or should I go? Career choice intentions of students with family business background. Journal of Business Venturing, 26(5): 521-536 